\title{
Civil Religion and the Establishment Clause
}

\author{
Yehudah Mirsky†
}

\section{INTRODUCTION}

An extensive religious dimension in American public life, one which finds expression in rhetoric, rituals and symbols, poses a long-standing problem in establishment clause ${ }^{1}$ jurisprudence. In this essay I will attempt a new approach to this problematic issue. First, I will trace the outlines of this public religion ${ }^{2}$ and the constitutional ambiguities that trail in its wake. I will then focus on two recent decisions, Marsh $v$. Chambers $^{3}$ and Lynch v. Donnelly ${ }^{4}$. In these decisions, the Supreme Court developed what amounts to a de facto exception to traditional establishment clause doctrine, one that. effectively allows government to acknowledge religion formally and publicly without somehow endorsing it. This doctrinal development is flawed in two respects: It is based on a misperception of the nature and origins of American public religion and creates as many constitutional problems as it purports to solve.

I will then look to recent scholarly discussion of the history and sociology of American religion, focusing on the distinction that has been drawn between civil religion, an essentially secular, political phenomenon, and traditional, sacral religion. After discussing the roots of civil religion in the American historical experience I will look at how the phenomenon has been evaluated in light of the concerns that animate the establishment clause and, finally, suggest that by recognizing the existence of a civil religion and putting that recognition to use, courts can make good constitutional sense of American public religion. ${ }^{5}$

† I would like to thank the late Rabbi David Mirsky, who through word and example taught me the nuance, complexity, and possibility of religious creativity in a modern world.

1. The Constitution provides, in relevant part: "Congress shall make no law respecting an establishment of religion. . "U.S. ConsT. amend. I.

2. The term "public religion" was coined by Benjamin Franklin. For an acoount of the term and its history, see M. Marty, PILgrims in Their OWN LAND: 500 Years of Religion in America 155-66 (1984). A similar locution that some readers may find helpful, though it has a somewhat different flavor, is Dean Rostow's "ceremonial deism," quoted in Sutherland, Book Review, 40 IND. L.J. 83, 86 (1964).

3. 463 U.S. 783 (1983).

4. 465 U.S. 668 (1984).

5. This essay rests on the premise that the questions and ambiguities surrounding the establishment clause are, at least to some degree, themselves functions of broader, long-term historical processes of secularization and modernization. Courts and commentators have all too frequently failed 


\section{The Problem of Public Religion}

In Marsh v. Chambers, ${ }^{\beta}$ the Supreme Court affirmed the constitutionality of a state legislature's opening its sessions with an ecumenical prayer by a Christian minister. In Lynch $v$. Donnelly, ${ }^{7}$ the Court allowed a municipality to erect a Nativity scene as part of its annual holiday display. These decisions have brought to the fore a tension in establishment clause jurisprudence between the constitutionally suspect character of a number of time-honored public practices and the widespread acceptance of a religious element in much of American public life as lived through public ritual and rhetoric. ${ }^{8}$ The texture of this public religion is not readily graspable, and its nature and status are not readily understandable in terms of conventional religious or legal categories.

Our public life is replete with examples of this ambiguous religion. We pledge allegiance to a nation under God, ${ }^{9}$ have a statutorily mandated National Prayer Day" and our national motto is "In God We Trust."11 This intersection of the religious with the political is also evident in some of our most treasured public texts such as Lincoln's Second Inaugural Address. ${ }^{12}$ Lincoln's speech is a moving, theologically inspired meditation on the ways of human sin and redemption and of divine providence and retribution. It is, of course, at the same time an interpretation of one of the most important political events in American history by a central participant in that event. Moreover, the American people regard the Second

adequately to note the broader social, political and ideological currents of which those issues are a part. See Johnson, Concepts and Compromise in First Amendment Religious Doctrine, 72 CaLIF. L. REv. 817 (1984) (establishment clause cases are political responses to complex, heterogeneous societal problems); Mansfield, The Religion Clauses of the First Amendment and the Philosophy of the Constitution, 72 CALIF. L. REv. 847 (1984) (religion clauses must be understood in context of world-view underlying American constitutional democracy).

This assumption in turn generates a methodological principle, namely that interdisciplinary perspectives on the establishment clause are helpful if not absolutely necessary. In this essay I will draw on two sorts of non-legal scholarly materials, historical studies on the one hand and interpretive social science on the other. As to the latter, see Dworkin, Social Sciences and Constitutional Rights-The Consequences of Uncertainty, 6 J. LAw \& EDuc. 3, 6 (1977) (arguing that interpretive social science can be helpful in adjudication as its analytic processes resemble those of common law reasoning). See generally InTERPRETive Social Science: A ReAder (P. Rabinow \& W. Sullivan, eds. 1974).

6. 463 U.S. 783 (1983).

7. 465 U.S. 668 (1984).

8. This public religiosity becomes particularly apparent at those times when politics interacts with what we may loosely call "culture," defined for our purposes as "an historically transmitted pattern of meanings embodied in symbols, a system of inherited conceptions expressed in symbolic forms by means of which men communicate, perpetuate and develop their knowledge about and attitudes toward life." C. Geertz, The Interpretation of Cultures 89 (1973).

9. 36 U.S.C. $\$ 172$ (1985).

10. 36 U.S.C. $\$ 169$ (h) (1985).

11. 36 U.S.C. $\$ 186$ (1985). For an historical account of the evolution of the Pledge of Allegiance and of "In God We Trust," see A. Stokes \& L. Pfeffer, Church and State in the United STATES 568-71 (1964).

12. Abraham Lincoln's Second Inaugural Address (March 4, 1865), reprinted in THE LIFE AND Writings of Abraham Lincoln 839-42 (P. Stern ed. 1940). 
Inaugural Address as a precious text not only by virtue of its rhetorical beauty and historical significance but also for its moral and spiritual content as well. We have no trouble with its presence on the walls of a national shrine. It somehow "feels" right.

Today's American public, however, is far less homogeneous than the American public of Lincoln's time, and many would feel uncomfortable with a contemporary Presidential address as laden with biblical rhetoric and ideas as was Lincoln's. ${ }^{13}$ Even so, we do continue to imbue our public image with a religious tone. For example, we revere Martin Luther King, Jr.'s deeply religious words in his "I have a dream" speech" as much as we do those of Lincoln, and many would gladly enshrine them on a national monument.

A host of practices, texts and symbols are readily classifiable in both political and religious terms. By making them part of our public and political life we accord them some legitimacy. But the Constitution forbids such legitimization if it leads to the establishment of religion. While our schoolchildren may, for example, be asked to recite the Second Inaugural in class, the Constitution forbids them from praying. ${ }^{15}$ In other words, public religion "feels funny," constitutionally speaking, and is not readily understandable or justifiable in the terms through which the establishment clause is generally understood.

There are three such frames of reference, each named for its earliest exponent. The Madisonian school sees the establishment clause primarily as a means of discouraging government by any one particular religious group while encouraging a multiplicity of mutually balancing sects, all competing for adherents and defining themselves in relation to each other, thus achieving a creative equilibrium. ${ }^{18}$ The Jeffersonian school's thrust, a more fundamentally negative one, speaks for varying strains of Enlightenment thought, all marked by a disdain for organized religion, ranging from a profound fear of theocracy to outright contempt for all clerics and

13. For a collection of recent Presidential statements of a religious cast, see R. REAGAN, In God I Trust (1984); for a critical discussion of this religious presidential rhetoric and its relation to the current political climate, see Krauthammer, The Church-State Debate, New RePUBLIC, Sept. 17, 1984, at 15; Krauthammer, America's Religious Wars, The New Republic, Apr. 9, 1984, at 15.

14. Address by Martin Luther King, Jr. in Washington, D.C. (Aug. 28, 1963), reprinted in S. OAtes, Let the Trumpet Sound: The Life of MARTin Luther King, JR. 253-55 (1984).

15. See Engel v. Vitale, 370 U.S. 421 (1962); Abington School Dist. v. Schempp, 374 U.S. 203 (1963).

16. The Madisonian position is set forth at length in the Memorial and Remonstrance Against Religious Assessments, reprinted as an appendix to Everson v. Board of Education, 330 U.S. 1, 63 app. (1946). The Madisonian formulation is fully discussed in Curry, James Madison and the Burger Court: Converging Views of Separation, 56 IND. L.J. 615 (1981). For an interesting contemporary restatement of the Madisonian emphasis on the importance and necessity of multiple factions and social sub-groups for the health of a vibrant democracy, see M. Novak, Democracy and Mediating Structures (1980). 
their beliefs. ${ }^{17}$ The third school of establishment thought traces its lineage to Roger Williams, the founder of Rhode Island, who sought disestablishment primarily in order to preserve the purity of the church itself and keep it free of the taint of political partisanship. ${ }^{18}$ All of these basic interpretations of the establishment clause are critical to the discussion inasmuch as they all reflect legitimate and mutually illuminating concerns that, historically and philosophically, were present at the creation of, and have given meaning to, the establishment clause. ${ }^{18}$

By any of these interpretations of the establishment clause, public religion is a very suspicious phenomenon. It threatens to vitiate a Madisonian commitment to pluralism and heterogeneity by infusing public and political life with the language and ideas of recognizably Judeo-Christian traditions. By Jeffersonian lights it could clearly operate as a vehicle for the establishment of a religious hegemony over the symbols and rhetoric of public discourse. And to a Williams-like sensibility it poses a significant threat to the purity of ecclesiastical institutions and to the transcendence of religious beliefs by its vague hallowing of public and political life.

This being said, however, any and all manifestations of public religion cannot be deemed unconstitutional outright, and therein lies the dilemma. While public religion is a constitutionally questionable phenomenon, it is equally true (as the above discussion makes clear) that it is a meaningful element of American life which most, if not all, of us would rather not see eliminated root and branch. Its abiding presence seems to speak to some curious need for religious symbols and rhetoric in a seemingly disestablished republic. We would do well, then, to articulate some sort of concept or category of sufficient explanatory weight and descriptive power to

17. See Letter from Thomas Jefferson to Dr. Benjamin Waterhouse (1822), reprinted in AMERICan Political. Theology 27-8 (C. Dunn ed. 1984) (expressing Jefferson's own view of disestablishment goal); see also Little, The Origins of Perplexity: Civil Religion and Moral Belief in the Thought of Thomas Jefferson, in American Givil Religion (R. Richey \& D. Jones, eds. 1974); S. HOOK, RELIGION IN A Free SOcIETY (1967) (recent formulation of Jeffersonian position); P. GAY, The Enlightenment: An Interpretation, The Rise of Modern Paganism (1966) (discussing European intellectual climate that gave birth to the Jeffersonian position).

18. See M. Howe, The Garden and the Wilderness (1965); see also E. Morgan, Roger Williams: The Ghurch and the STATE (1967) (discussing relationship between Williams' political thought and Puritan theology). I am indebted to Professor Perry Dane for introducing me to the subtlety and elegance of Williams' position.

19. See Smith, The Special Place of Religion in the Constitution, 1983 Sup. CT. Rev. 83 (noting that at one time or another all of these positions have been reflected in establishment clause jurisprudence).

My own sense is that these various interpretations of the establishment clause tend toward a similar direction, toward a notion of an open, heterogeneous, democratic republic in which the creative impulses and energies of religion could be given free rein without the threat of the horrific religious violence so characteristic of the European experience. This idea was best captured, I think, by Father Murray's notion of the religion clauses as the "articles of Peace". See J.MuRRAY, WE Hold These Truths 45 (1960); see also R. Neuhaus, The Naked Public Square: Religion and DemocRACY IN AMERICAN LIFE 114-28 (1984). 
make legal sense of public religion, rather than simply entrust constitutional judgments to raw intuition. The need for some sort of conceptual clarity here is evident from the judicial treatment of public religion and the inconsistencies this constitutional wild card has engendered. ${ }^{20}$

In an often-cited 1952 decision, Zorach v. Clauson, ${ }^{21}$ Justice Douglas, delivering the Court's opinion upholding a released-time program of religious education for school children, said that "[w]e are a religious people whose institutions presuppose a Supreme Being." ${ }^{\text {22 }} \mathrm{He}$ substantiated this idea by referring to various indicia of public religiosity, including courtroom oaths, religious language in presidential messages and, significantly, legislative prayer..$^{23}$

Notwithstanding this pronouncement, ten years later in Engel $v$. Vitale, ${ }^{24}$ Justice Douglas concurred in the Court's finding that even nondenominational prayer in the New York public schools was unconstitutional. He distinguished his Zorach opinion by implying that the latter referred to the lives of individuals and not to government activities. He did not, however, explain how he distinguished these unconstitutional programs from congressional and courtroom prayers, which he characterized as politically divisive, but not unconstitutional. ${ }^{25}$ Justice Stewart, dissenting in Engel, marshalled an impressive array of statutes and quotations from Lincoln, Woodrow Wilson, John F. Kennedy and others, all to the effect that we are, as Justice Douglas had said, a religious people. ${ }^{26}$

The Court echoed this recognition of the ubiquity and significance of public religion even as it struck down school prayer in Abington School District v. Schempp. ${ }^{27}$ While religious exercises in the schools were unconstitutional, the Court said, there was no blinking the fact that "religion has been closely identified with our government, ... . that the Founding Fathers believed devotedly that there was a God and that the unalienable rights of man were rooted in Him," and that "[t]his background is evidenced today in our public life." The Court concluded that, the unconstitutionality of school prayer notwithstanding, "today, as in the beginning, our national life reflects a religious people."28 In these decisions, the Jus-

20. I shall confine my discussion to the current era of establishment clause adjudication that was ushered in by Everson v. Board of Education, 330 U.S. 1 (1946). Prior to that, American public religion was avowedly sacral and sectarian, as evidenced by Justice Brewer's pronouncement that this is "a Christain nation," Church of the Holy Trinity v. United States, 143 U.S. 457, 471 (1892) (statute prohibiting importation of alien labor not applicable to importation of clergy).

21. 343 U.S. 306 (1952)

22. Id. at 313 .

23. Id. at $312-13$.

24. 370 U.S. 421,437 (1962) (Douglas, J. concurring).

25. Id. at $442-43$.

26. Id. at $446-45 \&$ n.3.

27. 374 U.S. 203 (1963) (recital of prayer in public school violates establishment clause).

28. Id. at 212-13. The Supreme Court has joined this issue in a context wherein the problem of 
tices of the Supreme Court were responding to a very real ambiguity, a tension between establishment clause concerns on the one hand and the reality and widespread acceptability of public religion on the other, which drove them to look to history and public sentiment rather than to principled analysis. ${ }^{29}$

In Marsh and Lynch, the Court held that legislative prayer and government-sponsored Nativity displays are constitutional. The former would seem to be of a piece with a host of practices widely regarded as commonplace and acceptable, such as courtroom oaths and swearings-in. On the other hand, government sponsorship of a display that depicts the miraculous birth of Jesus Christ seems to be a celebration of a purely religious moment. How, if at all, are Nativity scenes or legislative prayers to be distinguished from pledging allegiance to a nation under God? On the basis of the responses that we have examined thus far there is no way to distinguish them. As yet, we have no term, paradigm or category that can capture the subtle shadings of difference that make public religion different from that which ordinarily goes under the name "religion" in a way that will not do violence either to the establishment clause or to the American historical experience. We lack the sort of long-term, broadly based perspective that can enable us to make good constitutional sense of cultural and symbolic interactions between religion and government. ${ }^{30}$

public religion had certainly been a salient factor in other lower court decisions, namely the characterization of the Ten Commandments. In Anderson v. Salt Lake City Corp., 475 F.2d 29 (10th Cir.), cert. denied 414 U.S. 879 (1973), the Tenth Circuit upheld the erection next to a courthouse of a monolith bearing, among other symbols, the Ten Commandments, arguing that "the Decalogue is at once religious and secular." 475 F.2d at 33. Offhand, that position may seem plausible inasmuch as some of the Commandments (e.g. the prohibitions of theft and murder) are perfectly congruent with the laws of this country, while others (e.g. the recognition of God, the prohibition of false and useless oaths) would seem to comport nicely with some of the indicia of public religion that we have already seen, such as courtroom oaths and legislative prayer. Even so, in Stone v. Graham, 449 U.S. 39 $(1980)$, the Burger Court decided in a four-page per curiam opinion that posting the Decalogue in a classroom was clearly unconstitutional, unequivocally saying that "[t]he Ten Commandments are undeniably a sacred text." Id. at 41 . In a brief dissent, Justice Rehnquist cited Anderson and said that the Decalogue "as a whole has had significant secular impact." Id. at $45 \mathrm{n} .2$. While of course one can distinguish a public school from a courthouse or simply argue that one or the other was wrongly decided, it is nonetheless interesting to note that the Ten Commandments can be characterized as a sacred religious text, as a treasured part of the American heritage, or as both.

29. See Louisell, The Man and the Mountain: Douglas on Religious Freedom, 73 YALE L.J. 975, 996 (1964) (arguing that Justice Douglas' seeming about-face was in fact conscious attempt to force latent tensions to surface). The strained and complex character of Justice Douglas' Zorach opinion was recognized at the time by Justice Jackson who, writing in dissent, said that Zorach "will be more interesting to students of psychology and of the judicial processes than to students of constitutional law." 343 U.S. at 325.

30. Lurking beneath any discussion of the thorny nature of public religion is another question, the characterization of secular morality. The uncertain status of once-religious morality in an ostensibly secular age has generated significant discussion among philosophers and legal scholars alike. See Leff, Unspeakable Ethics, Unnatural Law, 1979 Duke L.J. 1229; see also A. MAcINTYRE, AFTER VIRTUE (2d. ed. 1984). For a comprehensive overview of the ways in which the ambivalent relationship between religious and secular moralities has surfaced in establishment and free exercise discussion and adjudication, see Note, Religion and Morality Legislation: A Reexamination of Establishment Clause 


\section{The Supreme Gourt's Problematic Solution}

The three-pronged test set forth in Lemon $v$. Kurtzman, ${ }^{31}$ which has served as the doctrinal keystone of establishment clause analysis for some time, has proved to be of little help in solving the puzzle of public religion. Instead, the Court has fashioned a new and problematic answer, an "acknowledgment" exception to the establishment clause.

Under the Lemon test, in order for a government activity to pass establishment clause scrutiny, it must have a legitimate secular purpose and must neither advance nor inhibit religion nor foster an excessive government entanglement with religion. ${ }^{32}$ While this test has lent some clarity and consistency to what otherwise could have been an unclear and ideologically volatile area of the law, it has not provided the Court with a useful response to the problem of public religion, for two reasons.

First, all of the key terms of the Lemon test suffer from the same ambiguities that have generated the problem of public religion in the first place. Is the pledge of allegiance a secular affirmation? Do courtroom oaths advance religion? Does "In God We Trust," without more, foster an excessive entanglement with religion? The answer, of course, is that it all depends on how public religion is characterized in the first place. Before the Lemon test can be helpful courts must first develop a sense of what it is talking about when discussing public religion.

Second, the Lemon test has itself fallen on hard times inasmuch as its seemingly crisp dichotomies (secular/religious, advance/not-advance, excessive/acceptable entanglement) are themselves not supple enough to do justice to the complex nature of church-state interaction, especially given the vast expansion in the range of activities undertaken by the government since the New Deal. ${ }^{33}$ In Marsh $v$. Chambers, ${ }^{34}$ when faced with the task

Analysis, 59 N.Y.U. L. REv. 301 (1984) (arguing that since all legislation is value-laden only values traceable to Constitution may be statutorily enforced).

31. 403 U.S. 602 (1971).

32. Id. at $612-13$.

33. This has become particularly evident in the context of what we may call welfare state/government largesse programs. This difficulty with the Lemon test made itself felt in last term's decision in Aguilar v. Felton, 105 S. Ct. 3232 (1985), in which the Court felt constrained to deny federal funding for special-education programs taught in inner-city parochial schools by public school teachers. A particularly thoughtful response to this sort of problem is Schwartz, Larkin v. Grendel's Den, the Burger Court and the Establishment Clause Problem, 21 Houston L. Rev. 179 (1984), which suggests that the Lemon test be bifurcated into two separate tests, one for reviewing financial aid to religious institutions, the other for reviewing doctrinal aid, that is, aid which formally recognizes the tenets or practices of a religion. Another commentator, grappling with the same problem, has offered a different alternative; a differentiation of establishment clause cases into four categories: public schools, non-public schools, regulation of religious organizations and practices that have long been part of the national community. See Note, Lynch v. Donnelly: Has the Lemon Test Soured?, 19 Loy. L.A. L. REv. 133 (1985). The distinction between doctrinal and financial aid has, in fact, been employed by the Supreme Court of California; see Note, Rebuilding the Wall Between Church and State: Public Sponsorship of Religious Displays Under the Federal and California Constitutions, 37 HAstrngs 
of evaluating the constitutionality of the Nebraska legislature's practice of opening its sessions with a prayer led by an ordained minister who was paid out of public funds, the Court chose simply to ignore the Lemon test. Writing for the majority, which held the prayer to be constitutional, Chief Justice Burger looked instead to legislative prayer's long and venerable history, stretching back to the First Congress. Then, in a passage laden with mythic resonance ${ }^{38}$ he said that "[t]o invoke Divine guidance on a public body entrusted with making the laws . . . is simply a tolerable acknowledgment of beliefs widely held among the people of this country." ${ }^{\text {"36 }}$ The dilemma faced by the Court was quite real. By conventional indicia of establishment as understood in terms of the Lemon test, legislative prayer is indeed questionable. ${ }^{37}$ The legislative imprimatur thus bestowed on prayer clearly advances religion, specifically, the particular denomination which the minister represents. The choice of which clergy to ask to serve as leaders of prayer entangles the government in picking and choosing among denominations. Yet, how could something that has been done so respectably for so long be unconstitutional? Faced with the task of making judicial sense of public rituals and symbols of a somewhat religious cast, the Court attempted a broader formulation of the nature and value of public religion. Specifically, the Court looked for guidance to historical accounts of the Framers themselves and of the First Congress. ${ }^{38}$ The Chief Justice concluded that public religion is not an unconstitutional establishment but rather a recognition by the government that the major-

L.J. 499 (1986).

34. 463 U.S. 783 (1983).

35. One critic has noted a recurring tendency of the Chief Justice to invoke communitarian imagery as a source of validation for government practices that skirt the constitutional line. See Chesler, Imagery of Community, Ideology of Authority: The Moral Reasoning of Chief Justice Burger, 18 Harv. G.R.-C.L. L. Rev. 457 (1983).

36. 463 U.S. at 792 .

37. At bottom, the legislature is being led in communion with the deity through the offices and inspiration of a man of the cloth. Moreover, the very structure of the act of prayer in the Western tradition is itself fraught with theological assumptions. On the theology of prayer, see A. Heschel, QUEST FOR GOD (1954).

38. One commentator has noted the ironic fact that while the Burger Court has put history to work in its establishment clause cases in order to accommodate religious institutions and beliefs, traditionally it has been a weapon in the arsenal of strict separationists. See Redlich, Separation of Church and State: The Burger Court's Tortuous Journey, 60 NoTRE DAME L. Rev. 1094, 1120-22 (1985). Moreover it is worth noting that the Court is not looking to the constitutional ideas of the Framers as much as to the social and cultural milieu in which they lived.

The relevance of the social and intellectual history of the Framers to constitutional adjudication presents extraordinarily complex questions that lie beyond the purview of this essay. On the uses of history generally, see Powell, The Original Understanding of Original Intent, 98 HARV. L. REv. 885 (1985) (the Framers themselves did not intend their intent to be normative); Simon, The Authority of the Framers of the Constitution: Can Originalist Interpretation Be Justified?, 73 CALIF. L. REV. 1480 (1985) (arguing that it cannot); Wofford, The Blinding Light: The Uses of History in Constitutional Interpretation, 31 U. ChI. L. REv. 502 (1964) (history is only a reliable guide to understanding evils that an enactment was designed to counteract). 
ity of this country's inhabitants adhere to certain religious beliefs. Thus the organs of state are not in any way creating or establishing a religion, they are simply fashioning shared enactments out of "particles of ritual"39 supplied by the people themselves. ${ }^{40}$

The Court took the "acknowledgment exception" even further in Lynch v. Donnelly, ${ }^{11}$ when it upheld the inclusion of a Nativity scene in the annual holiday display of Pawtucket, Rhode Island. Chief Justice Burger, again writing for the majority, disposed briefly of the Lemon test by referring to it as more of a guideline than a test. ${ }^{42} \mathrm{He}$ then examined the question at hand in light of the "unbroken history of official acknowledgment by all three branches of government of the role of religion in American life." Noting that "our history is pervaded by expressions of religious beliefs,"44 and that the Nativity scene appeared in what was clearly just a holiday display, he saw no constitutional infirmity.

The logic of Marsh led in a clear line to the result in Lynch. Once the government is allowed to acknowledge religions that have been around and widespread for a long time, there can be nothing wrong with its commemorating the founding moment of Christianity. William Van Alstyne has characterized the Court's reasoning in Lynch as an "any more than" test, under whose terms government sponsorship of a religion is unobjectionable if it is no more than what the government has done in the past. ${ }^{45}$ The legitimate functions of government are defined here simply by what government is already doing, without any reference to the substantive content and constitutional value of the activity in question.

Justice O'Connor recognized the problematic nature of the acknowledgment exception and took pains in her concurring opinion to distinguish acknowledgment of religion from an impermissible endorsement of religion. "[G]overnment acknowledgments of religion," she wrote, "serve, in

39. The phrase originates with F. Wallace, cited in J. WiLson, PUBLIC RELIGION IN AMERICAN Culture 166 (1979).

40. The Marsh opinion has been subjected to a great deal of criticism. See Note, The Lemon Test Soured: The Supreme Court's New Establishment Clause Analysis, 37 VAND. L. REv. 1175 (1984); Note, Legislative Prayer and the Establishment Clause: An Exception to Traditional Analysis, 17 CReighton L. Rev. 157 (1984); Drakeman, Antidisestablishmentarianism: The Latest (and Longest) Word From the Supreme Court in Marsh v. Chambers, 5 Cardozo L. Rev. 153 (1984).

41. 465 U.S. 668 (1984).

42. Id. at 679. The Lemon test did reappear in attenuated form in the opinion when the Chief Justice said that the holiday setting and commercial context of the display rendered it secular. Id. at 681.

43. Id. at 674 .

44. Id. at 677 .

45. Van Alstyne, Mr. Jefferson's Crumbling Wall-A Comment on Lynch v. Donnelly, 1984 Duke L.J. 770, 783; Note, Lynch v. Donnelly: Breaking Down the Barriers to Religious Displays, 71 CoRnell L. REv. 185, 207 (1985) has similarly noted that the acknowledgment exception constitutes a step in the direction of accommodating government to religious beliefs and institutions.

46. Lynch v. Donnelly, 465 U.S. 669, 687-94 (1984) (O'Connor, J., concurring). 
the only ways reasonably possible in our culture . . . [to] solemniz[e] public occasions, express confidence in the future, and encourag[e] the recognition of what is worthy of appreciation in society."4? By the terms of Justice O'Connor's reasoning, while the acknowledgment exception is not designed to equate good citizenship with a belief in the tenets of any religion in particular, it does accord government the prerogative to express "what is worthy of appreciation in our society" in terms of religious symbols, rituals, institutions and language. Indeed, to her mind, such religious terms and language are "the only ways reasonably possible" to do so. In her view, public religion is a response to a genuine need for the solemnization and elevation of certain public moments, for the creation of a public language that can express and accommodate the abiding values and commitments shared by most, if not all, the members of our society. Although Justice O'Connor recognized, in a way that the Ghief Justice did not, the dangers inherent in the acknowledgment exception, the importance of public solemnification, to her mind, adequately justified the result in Lynch.

The acknowledgment exception fails to make constitutional sense of the problem of public religion. First, it is an inherently unprincipled way of dealing with an elusive problem, relying more on intuition and a devotion to the status quo than on reasoned analysis. To say that what we really mean by public religion is government acknowledgment of religion is at best simply to restate the problem, if not to exacerbate it by according government a legitimate role in the shaping of public religion. The terms of the exception itself are by no means as clearly defined as they should be: Can the government acknowledge any religion in any way it chooses? Even according to Justice O'Connor's somewhat guarded formulation of acknowledgment, at what point would it shade off into an impermissible endorsement?

Second, even if we could make sense of the idea of acknowledgment on its own terms, it would fail to pass muster by all three of the establishment frames of reference outlined above. ${ }^{48}$ In both Madisonian and Jeffersonian terms, acknowledgment of religion associates the unquestioned primary legitimacy of government with the ubiquity of religious symbols and language. The inherent selectivity of what religion to acknowledge and in what manner will of necessity throw the weight of government behind certain sects and factions at the expense of others. ${ }^{49}$ Finally, in

47. Id. at 693.

48. See supra text accompanying notes 16-19.

49. Local communities are likely to put acknowledgment doctrine, articulated in terms of "unbroken histories" and "what is best in our society," into effect by acknowledging what they feel most comfortable with, namely Protestantism and, to a lesser extent, tepid Judaism and Catholicism, to the exclusion of the less familiar variants of those traditions and certainly of non-Western religions. For 


\section{Civil Religion}

Roger Williams' terms, what could degrade the moment when the Word was made flesh more than relegating it to the status of a lawn flamingo-acceptable, not because of its revelatory truthfulness but by virtue of its ubiquity and banality? Roger Williams would not have wanted us to stake public religion's legitimacy on its irrelevance. Clearly, the acknowledgment exception is an unsatisfactory solution to the problem of public religion.

\section{Givil Religion: A Better Solution}

An examination of recent scholarly discussion of the social and cultural history of American religion in general, and the phenomenon known as civil religion in particular, will enable us to formulate a more coherent legal response to the constitutional problems raised by public religion. In this Section of the essay I will first describe how scholars have employed the idea of civil religion as a helpful tool for the understanding of American public life, and then evaluate the implications of these insights for constitutional adjudication under the establishment clause.

\section{A. What is "Civil Religion"?}

In scholarly discussions of religion generally, the word "religion" has not been taken to refer to specific creeds or sects. Religion, rather, is understood in functional terms, as a phenomenon that plays a specific role in the lives of individuals and societies. ${ }^{30}$ This conception of religion not only provides a degree of analytic clarity that is absent from content-oriented definitions of religion, but also makes for illuminating cross-cultural analyses of the roles that different religions play in their respective societies and cultures.

It was with this functional conception of religion in mind that in 1967, Robert N. Bellah, a sociologist, introduced the term "civil religion" into

\footnotetext{
an extensive discussion of the selectivity and bias inherent in all government recognitions of religion, see Florey v. Sioux Falls School Dist. 49-5, 619 F.2d 1311, 1320-30 (8th Cir.) (McMillan, J., dissenting), cert. denied, 449 U.S. 987 (1980); see also Note, Indian Religious Freedom and Governmental Development of Public Lands, 94 Y ALE L.J. 1447 (1985); Note, Soul Rebels: The Rastafarians and the Free Exercise Clause, 72 Geo. L.J. 1605 (1984) (discussing shabby treatment that nonWestern religions have generally received at the hands of American courts).

50. Clifford Geertz's definition of religion is a good example. He defines it as "a system of symbols which acts to establish powerful, pervasive and long-lasting moods and motivations in men by formulating conceptions of a general order of existence and clothing these conceptions with such an aura of factuality that the moods and motivations seem uniquely realistic." C. GEERTZ, supra note 8, at 90. Of the innumerable works written on the subject of comparative religion, I have found the following especially helpful: W. JAMEs, The Varieties of Reugious EXPERIEnCE (1902); E. CasSIRER, ESSAy ON MAN (1944); The History of Religions: Essays IN METHodology (M. Eliade \& J. Kitagawa, eds. 1966); T. O'DeA, Soctology of Religion (1983); G. Scholem, MAJOR TRENDS IN JEWISH MYSTICISM (1946).
} 
contemporary discussion. ${ }^{\mathbf{5 1}}$ Bellah's idea, it seems to me, is traceable to two intellectual currents. One is the tradition of Emile Durkheim, who had written extensively on the ways in which religions glue society together, linking senses of past, present and future with communal institutions and authority. ${ }^{52}$ The other is a tradition of social criticism, starting with de Tocqueville, that had noted a congruence between the tenets of American religious denominations and the American democratic ethos. This congruence perplexed sociologists and vaguely troubled theologians inasmuch as American Protestantism seemed to exhibit an enthusiasm for pluralism, representative government and private enterprise that most historians of religion would find, to say the least, unfamiliar. ${ }^{53}$ Continuing in this vein, Bellah suggested that

there actually exists, alongside of and rather clearly differentiated from the churches, an elaborate and well institutionalized civil religion [i.e.] certain common elements of religious orientation that the general majority of Americans share [and that] have played a crucial role in the develoment of American institutions and still provide a religious dimension for the whole fabric of American life, including the political sphere. ${ }^{54}$

This civil religion, it seemed to Bellah, was a sort of millenarian Protestantism that had been secularized and assimilated into American culture, eventually taking the form of a comprehensive set of values, symbols, rituals and metaphysical assumptions, all centered around and rooted in the interpretation of the American historical experience.

Bellah's evocative essay has generated a sizable body of scholarly comment and discussion. ${ }^{65} \mathrm{He}$ had disclosed a new source of metaphors on which we could draw in trying to explain American political life, language and ritual. . $^{\text {s }}$

51. Bellah, Civil Religion in America, Daedalus, Winter 1967, at 21.

52. For a brief account of Durkheim's thought, see A. Giddens, Emile Durkheim (1979).

53. See A. DE Toceueville, Democracy in AMErica 22-32 (1974 ed.). For the best-known latter-day observation of this strange congruence, see W. Herberg, Protestant Catholic Jew (1955). Herberg was the first to notice that the American Way of Life seemed to so tailor traditional religious social patterns and doctrines that it was, in effect, a new hybrid American religion. In this, as in so much else, this neglected, enigmatic thinker was ahead of his time.

54. Bellah, supra note 51 , at 24 .

55. Some of the most significant contributions to the literature that has sprung up in response to Bellah's essay are: American Civil. ReLigion (R. Richey \& D. Jones eds. 1974) [hereinafter referred to as Richey \& Jones]; S. Mead, The Nation With the Soul of a Church (1975); J. Wilson, PUblic ReLigion In AMERICAN Culture (1979). For an account of the progress and political uses of the scholarly discussion, see M. MARTY, A NATION OF Beravers 180-203 (1976).

56. This use of non-political metaphors in a political setting can be compared to Hobbes' and Locke's use of legal metaphors, contract in particular, in trying to understand the new political arrangements of Western nation-states. J. Pocock has argued that a significant first step in all political thinking is the decision to look to a certain, specific field of human endeavor (be it religion, law, 


\section{Civil Religion}

Professor West has suggested a definition of civil religion that captures its essentially political nature. He defines civil religion as "a set of beliefs and attitudes that explain the meaning and purpose of any given political society in terms of its relationship to a transcendent, spiritual reality, that are held by the people generally of that society, and that are expressed in public rituals, myths and symbols." ${ }^{307}$ By constructing civil religions, the members of societies in the United States and elsewhere ${ }^{68}$ hallow their political life, expressing and reinforcing their most abiding values and senses of social self.

\section{B. Religions Civil and Sacral}

In distinguishing civil religion from that which we traditionally think of as religion, two elements seem particularly salient. ${ }^{58}$ First, civil religions as we have come to understand them are modern phenomena and are part of long-term societal responses to problems that were generated by the advent of modernity. Second, civil religion's focus is not sacral, as is generally the case with religions, but political.

One of the hallmarks of modernity is the dissolution of the senses of organic unity, solidarity and hierarchy, ${ }^{60}$ cosmic as well as earthly, that characterized pre-modern societies. A number of long-term developments-the advent of the nation-state, the Protestant Reformation and the weakening of the Church's intellectual authority, the growth of capital, industrial economies and the new forms of social organization that they engendered-loosened the traditional ties that had bound Western societies, forcing them to come up with new means of attaining and expressing social cohesiveness. ${ }^{61}$ The fragmentation and subsequent compartmental-

economics, music, or engineering) for the basic metaphors that we will use in explaining our political life to ourselves and to others. J. Pocock, Politics, Language and TIme: Essays on Political Thoughr AND History 1-41 (1973). I suspect that it is in light of this insight that we ought to assess Bellah's contribution.

57. West, A Proposed Neutral Definition of Civil Religion, 22 J. of ChuRch \& STATE 23, 39 (1980).

58. For comparative studies, see R. Bellah \& P. Hammond, Varieties of Givil Religion (1980); see also C. Liebman \& E. Don-YehiYA, Crvil Religion in IsRael (1983).

59. While I am of course wary of generalizations and conclusory statements in any discussion of so intricate and complex a subject as religion, some such generalizations and conclusions are necessary
if this essay is to contribute to any legal discussion.

60. See A. Lovejoy, The Great Chain of Being (1960).

61. The literature is, of course, voluminous. A helpful sketch of these developments is to be found in G. Poggi, The Development of THE Modern State: A Sociological. Introduction (1978). Another helpful and illuminating volume to which I can point is I. BERLIN, VICo AND HERDER: Two STUDIES IN THE History OF IDEAS (1976). By focusing on Giambattista Vico and Johann Herder, the progenitors of the modern ideas of culture and nation, respectively, Berlin is able to capture and describe a number of the most significant intellectual and cultural characteristics of modernity: in particular, a growing perception of culture; of a society's life as a wholly man-made web of interlocking fields of concern; and a turn towards nationhood as a source of meaning. 
ization of experience into categories such as "religion," "science," "ethics" and "social life" is part of a distinctly and characteristically modern sensibility. ${ }^{62}$ We can say that pre-modern societies were more "religious," in the sense that religious ideas and institutions were more closely bound up with a broader range of social, political and personal concerns than they are in modern societies.

By developing and nurturing civil religions the members of modern societies attempt to recapture some of the lost, organic solidarity of premodern societies by linking political ideas and institutions, naturally shared by all, with a network of hallowed meanings. By so doing, a society can link its political ideas and institutions to its basic, heartfelt sentiments and aspirations. ${ }^{63}$

A second characteristic of civil religion is its essentially political, nonsacral character. While traditional religions have, at least in the West, taken politics very seriously, ${ }^{64}$ they have generally done so in the name of something sacred. ${ }^{85}$ Civil religions, on the other hand, train their gaze on politics. Political life is the source of their concerns and provides the raw material for rituals, moments and imagery. Civil religions are created in response to new political arrangements and are devoted to making sense of and justifying those arrangements in terms that all members of the polity can understand and find compelling and meaningful. Though not sacral in itself, a civil religion draws on the various sacral religious traditions of a society. The transcendent cast of civil religions differentiates them from ideologies $^{68}$ in that the latter have none of the ultimacy ${ }^{67}$ or formal structure of traditional, sacral religions. A civil religion gathers and expresses the most deeply felt, abiding ideals and attitudes of a society's political

62. This facet of modern consciousness has been characterized as the "pluralization of social lifeworlds," see P. Berger, B. Berger \& H. Kellner, The Homeless Mind 63-82 (1974). On early manifestations of the mutual estrangements of religion, morality and science in particular, see $B$. Willey, The Seventeenth Century Background 24-40 (1949).

63. This is particularly true of democratic societies which, unlike their fascist or communist counterparts, cannot simply make politics the religion of the state.

64. Pre-modern and modern Judaism, for example, exemplifies an eminently social and political sacral religion. See Kinship and Consent: Studies in the Jewish Political Tradition (D. Elazar ed. 1981); see also Lichtenstein, Church and State: The Case for Interaction, 15 JUDAISM 387 (1966).

65. The classic expositions of the idea of sacrality as the hallmark of religious consciousness are R. Otro, The Idea of the Holy (1959 ed.); M. Eliade, Sacred and Profane (1959). For an application of the idea of sacredness to the long-standing problem of the constitutional definition of religion, see Note, The Sacred and the Profane: A First Amendment Definition of Religion, 61 TEx.

L. REv. 139 (1982).

66. See M. Henry, The Intoxication of Power: An Analysis of Civil Religion in ReLATION TO IDEOLOGY (1979) (civil religion has an ultimate normative dimension that sets it apart from ideologies that simply reify day-to-day interests of states).

67. My language here is deliberately reminiscent of Paul Tillich's characterization of religion as the sphere of "ultimate concern." See P. Tillich, Dysamics of Farth 1 (1958). 
life. By drawing on the form and language of sacral religion it achieves a special resonance and power.

\section{American Civil Religion}

We can breathe some life into these abstractions by looking at American civil religion, which drew on religious resources supplied primarily by Puritanism in response to the disestablishment demanded by the newly independent, quintessentially modern American republic. ${ }^{88}$ Disestablishment dissolved the State's traditional institutional locus of morality and left a vacuum in the body politic. To fill this vacuum, the American republic, like other modern republics, sought alternative sources of public morality and virtue. ${ }^{69}$ As part of the societal response to disestablishment, the courts started to fill the need for austere, normative political and moral authority, a mantle they wear to this day. ${ }^{70}$ Answering more directly to the need for some sense of transcendent unity, an American civil religion developed to fill the gap left by the demise of the established church. This civil religion, not surprisingly, has drawn on both the forms as well as the ideas of Judeo-Christian religion. In particular, civil religion has drawn on the rich mythic heritage of Puritanism.

American civil religion, following the forms and structures of JudeoChristianity in general, and Protestantism in particular, finds expression in myths of origin and eschatology, of first and last things (the Revolution, the Boston Tea Party, the Great Society, the American Century); a pantheon of heroes, saints and martyrs (the Founding Fathers, the fallen Lincoln, the Unknown Soldier); sacred places (the Lincoln Memorial, Plymouth Rock); a liturgical calendar of consecration and remembrance (the Fourth of July, Memorial Day, Thanksgiving); sacred texts (the Declaration of Independence, Lincoln's Second Inaugural Address); and an allembracing world-view (the American Way of Life, the Four Freedoms). Individually, each one of these things could be taken as just another public ritual or political artifact. Taken together, however, they add up to some-

68. This analysis is offered by Bellah \& Hammond, supra note 58, at 168-76; See also P. Williams, Popular Religion in America 168-76 (1980).

69. See G. WoOd, The Creation of the American Republic, 1776-1787, 427-29 (1960); J. Pocock, supra note 56, at 80-103. Both Pocock and Wood discuss the need of democratic republics for institutions that can somehow promote the civil virtue necessary for the survival of democracies, educating and socializing citizens into altruistic conceptions of enlightened self-interest. Wood, in particular, describes how religious institutions were looked to in that regard during the early years of the newly-founded American republic.

70. See Lerner, Constitution and Court as Symbols, 46 YALE L.J. 1290 (1937); Grey, The Constitution as Scripture, 37 STAN. L. REv. 1 (1984). The perception lying at the heart of these articles is that, beyond their function as authoritative sources of political decision, courts and the Constitution serve an important expressive function, inasmuch as they are, to the mind of the body politic, powerful symbols of cohesion and legitimacy. 
thing more, something best captured by the word "religion". They comprise an integrated network of rituals, meanings and symbols through which American society tries to express the deepest truths of its political life. Together these forms of articulation shape the frameworks of activity and attitude through which civil religion drives, and is in turn driven by, the political culture of the citizenry. American historical experience becomes refracted through a prism of religious thought and ideas. While each individual bit of myth or memory is not a whole religion, taken together they do take on the lineaments of one.

Five general themes have emerged in scholarly discussion of the substantive ideas and values expressed by and through American civil religion. ${ }^{71}$ They are, briefly, a sense that there is some sort of transcendent principle of morality to which this polity is, or ought to be, responsible; ${ }^{72}$ a faith in democracy as a way of life for all people and a concomitant belief in an American mission to spread it the world over; ${ }^{73}$ a sense of civic piety, that exercising the responsibilities of citizenship is somehow a good end in itself; ${ }^{74}$ a reverence for American religious folkways; ${ }^{75}$ and a belief that Destiny has great things in store for the American people. ${ }^{78}$

The existence of an American civil religion and its affinities and similarities to traditional, sacral religion have clearly been the source of much of the Court's confusion in its interpretation of the establishment clause. The problem has been that, given the absence of civil religion from the judicial lexicon, courts have been deprived of a valuable analytic tool and source of historical understanding. They have not had at their disposal an adequate set of paradigms and metaphors with which they could capture the contours of public religion. Nor have courts recognized that when we embrace religious metaphors in our public life we are not acknowledging some tepid form of any sacral religion. Rather, all these transcendent images have worked their way into our public life and culture as part of a religion of their own-not a "religion" in the colloquial sense, to be

71. See Jones \& Richey, The Civil Religion Debate, in RICHEY \& JONES, supra note 55, at 3.

72. See Mead, The Nation With the Soul of a Church, in Richey \& JoNEs, supra note 55, at 59-63: "the spiritual core which identifies [America] as a nation is the conception of a universal principle which is thought to transcend and include all the national and religious particularities ... the religion of the republic is essentially prophetic ... its ideals and aspirations stand in constant judgment ..."

73. See Watts, Robert N. Bellah's Theory of America's Eschatological Hope, 22 J. OF CHuRCH \& STATE 5 (1980) (arguing that, at least according to Bellah, the history of America and its civil religion is to be interpreted as a successive series of emergences and repressions of eschatological hope).

74. See Wilson, supra note 55, at 136-41; see also S. Bercovitch, The Puriran Origins of THE AMERICAN SELF 17-18 (1975) (contrast between personal responsibility and individualism lay at the heart of Puritanism).

75. See Warner, An American Sacred Ceremony, in RICHEY \& JoNES, supra note 55, at 89.

76. S. Bercovitch, The American Jeremiad 23, 78 (1978) (one of major themes of American Puritanism was promised American future). 
sure-but a religion nonetheless. The motto "In God We Trust" and Lincoln's Second Inaugural Address are not just the remnants of some pre-constitutional Christianity; they are the constituent parts of a longterm response to disestablishment. Good or bad, an American civil religion exists and the courts should avail themselves of the array of interpretive sources and insights that have illuminated it."7

\section{Is Civil Religion a Good Thing?}

In order to consider how to apply civil religion in an interpretation of the establishment clause, it must be evaluated in terms of the concerns lying at the heart of the clause, namely Jeffersonian fears of clericalism, Madisonian desires for pluralism and Williams' concern for the purity of the ecclesia. While some scholars have seen civil religion as a valuable response to an important need of disestablished societies, others have severely criticized both the phenomenon itself and the particular way in which it has been characterized. These criticisms have been of two sorts-one theological, the other political-and both implicate establishment clause values of pluralism, freedom from clerical tyranny and respect for the purity of religious beliefs and institutions. ${ }^{\text {78 }}$

The theological critiques run roughly as follows: Civil religion is the product of deep tensions and confusions, and not at all a step in the direction of their resolution. It is the episodic, un-systematic expression of confused societies, caught up in wrenching processes of religious and social change far beyond their comprehension and control. It is, in the words of one scholar, "a somewhat schizoid blend of Puritanism and the Enlightenment, of coercion and persuasion, of Jehova the god of battles and the mild and tolerant god of nature."79 This inchoate jumble of millenarianism coupled with American nationalism, these critics would say, can hardly be viewed as a source of communal strength and inspiration. The most charitable thing we could say about civil religion is that Americans have picked through some of the ruins of the great medieval cathedrals, taken a rafter here, a pew there and the shards of a stained-glass window, thrown them all together and called it a house. Moreover, the very thought of a religion of the republic as a substitute for a lost, pre-modern

77. The materials cited throughout this essay should, if nothing clse, indicate the richness of the scholarly materials available to the courts.

78. While these two sets of criticisms share some common concerns, I have sifted them out for the sake of analytic clarity.

79. Hughes, Civil Religion, the Theology of the Republic and the Free Church Tradition, $22 \mathrm{~J}$. of Church \& State 75, 77 (1980). 
faith is downright idolatrous, or, in Roger Williams' terms, a fantastic degradation and parody of religion. ${ }^{80}$

The various critiques of civil religion that can be grouped under the rubric of political criticism take as their starting point the fact that when talking about civil religion we are, at bottom, talking about myths. ${ }^{81}$ More to the point, we are talking about a political mythology, a cluster of myths that reinforce one another and constitute the historical or quasi-historical elements of a political order. ${ }^{82}$ Political myths, civil religion among them, are not only inclusive, binding the members of a polity around a common core of memory and observance; they are exclusive as well, identifying insiders and outsiders according to the predilections of those who generate society's myths and values. The relative cultural and spiritual homogeneity of our myths runs counter to Madison's ideal of disestablishment.

And myths can deceive. The tone of American civil religion is more often than not celebratory and there is never a hint that the martyrs might have died in vain. America's moral failings, as a democracy and as a nation ostensibly under God, are glossed over. ${ }^{83}$ The exclusion of any memory of the fate of this continent's natives, or of the miseries inflicted on women, immigrants and racial and ethnic minorities from the collective memory embodied in civil religion is indeed disturbing, not least from a Jeffersonian perspective. To the extent that civil religion allows us to forget or perpetuate past injustices, it corrupts the polity and its government's ability to function wisely. It is worth noting that this sort of selective reading of history is itself not infrequently characteristic of traditional, sacral religions. ${ }^{84}$

While these criticisms are formidable, to ignore civil religion's existence would be simply to blink reality; its existence is evident and has troubled

80. See Gleason, Blurring the Line of Separation: Education, Civil Religion and Teaching About Religion, 19 J. of Church \& STATE 517 (1977); see also Herberg, America's Civil Religion: What It Is and Whence It Comes, in RICHEY \& Jones, supra note 57, at 76. For an expression of fear of a hegemonic, quasi-religious secular ideology, see Murray, Law or Prepossessions?, 14 J. LAw \& Contemp. Prob. 23 (1949).

81. For a helpful introduction to a complex subject, see E. Gassirer, Language and MYTh (1946).

82. For an excellent presentation of the idea of political mythology, see L. Thompson, ThE Political. Mythology of APARTHeid 1-24 (1985).

83. See Long, Civil Rights-Civil Religion: Visible People and Invisible Religion, in RicHey \& JONES, supra note 55, at 211 (civil religion is a "hermeneutic mask" with which the white man obscures his checquered past from view). An evangelical criticism of the idea that America can honestly portray itself as an historical exemplar of Christian morality is to be found in M. NoLL, N. Hatch \& G. Marsden, The Search for Christian America (1983).

84. One particularly subtle (though well-intentioned) form of this obfuscation is the emergence in recent years of the locution "Judeo-Christian tradition" which, while it has some rough descriptive weight, papers over the literally and figuratively tortuous relations that have generally obtained between Jews and Christians over the past twenty centuries. See A. CoHEN, The Myth of THE Judeo-Christian Tradition (1971). 
the Court even in separationist decisions. ${ }^{85}$ Moreover, we can guardedly say that a self-conscious and critically reflective civil religion can play a positive role in cementing the communal symbolic life of American society. When faced with questions arising out of the social context of civil religion, courts must somehow tread a line between the expression of shared and constitutive values on the one hand and impermissible establishment on the other. Recognition of the idea of civil religion and the scholarly comment surrounding it can be of great help to courts. They can better understand just what the practices at bar are, what social function they fulfill and from whence they have come. On this basis, the courts can then proceed to employ whatever analytic categories they wish, without falling into the trap of mistaking civil religion for its sacral, traditional counterpart.

\section{Givil Religion in Adjudication}

By recognizing the phenomenon of civil religion in establishment clause adjudication, courts can make better sense of existing public religion and avoid undue and constitutionally illegitimate inferences from civil religion to traditional, sacral religion. In addition, this recognition could allow courts to shape the more troubling manifestations of civil religion into a more constitutionally palatable form. Of course, the formulation of adequate legal responses to subtle, symbolic webs of thought and imagination created independently of the judiciary and Congress cannot be reduced to an algebraic equation or dispositive litmus test. Rather, the courts can develop a sensibility from the extra-legal scholarly literature discussed here, a judicial sensibility that could respond creatively to the constitutional vagaries of public religion. ${ }^{86}$

In Marsh, a consideration of civil religion would have provided the Court with the following insights: Although prayer is, of course, an eminently religious activity, it is also a manifestation of one of the five substantive themes of our civil religion articulated above-the sense of re-

85. See supra text accompanying notes $21-29$.

86. The macrocosmic scale of socio-historical research and its reaching for generalizations is thought by some to be incommensurate with the eminently microcosmic, case by case scale of adjudication, see Collins, The Use of Social Research in the Coutts, in NAT'L Research CounciL, KNOwLedge and Policy: The UnCertain Connection 143-83 (1978).

Nonetheless there is much to be said for creative interaction between historical research and legal policy-making, for several reasons. Historical research dispells the timeliness from policies and practices and makes them stand unadorned and with their contingency in full view, and can keep us from maintaining a status quo simply by virtue of its stasis. If nothing else, historical research can steer policy makers towards better myths through critical history. See D. RoTHMAN \& S. WHEELER, SoCial History ANd Social Policy 5-8 (1981). These perspectives of demystification and creative re-examination in full knowledge of the thick contexts in which social life is lived and policy is made can be especially helpful when dealing with as myth and value-laden an activity as public religion. 
sponsibility to a transcendent principle of morality. If the Court had recognized that valuable civil goal of moral reflection, it could identify means of effectuating that goal without recourse to sacral religious prayer. What seems important to us about legislative prayer can be preserved without offense to the Constitution by having, say, an elder member of the house open the session with a reading of the Declaration of Independence or Learned Hand's famous "Spirit of Liberty" speech, ${ }^{\mathbf{8 7}}$ or simply with the very evocative ritual of a moment of silence. ${ }^{88}$ Given the existence of these alternatives, which could of course be suggested in dicta, a court could find legislative prayer as presented in Marsh unconstitutional without striking down a treasured vestige of the American heritage.

In Lynch, the Court could have recognized that while Nativity scenes have long been a part of American religious folkways, they are traditional, sacral symbols that have no place in front of City Hall. The idea of civil religion could have been successfully employed as a way of distinguishing the Nativity of Christ from the pledge of allegiance and other practices of civil religion that we are willing to accept by pointing to the essentially political character of the pledge, couched in religious terminology though it may be. Moreover, the concerns to which civil religion addresses itself, the fostering of a unified, cohesive sense of social identity for all members of the polity, militate against the erection of a Nativity scene, a religious representation that is meaningful only to some (even if to many) citizens and not to others.

To think of other examples: A court could comfortably find a Martin Luther King memorial constitutional, because the significance of his life and words derives not from his stature as a religious leader but as a major participant in one of the great political struggles of American history. A consideration of the values we nurture through our civil religion helps us understand just why it is that we are commemorating Martin Luther King. A constitutional challenge to National Prayer Day could be met by suggesting a National Day of Reflection that would preserve the essentially transcendental character of the day without casting it in traditional, sacral terms. A challenge to the motto "In God We Trust" could be met with the recognition of the importance of a unified national expression of faith, and a suggestion for a less sacral alternative.

By familiarizing themselves with the notion of civil religion, courts can develop the tools with which to consider public rituals and symbols within

87. L. HANd, The SpIRIt OF Liberty 189-91 (1960).

88. The Supreme Court has recently acknowledged the constitutional acceptability of moments of silence. In last term's decision in Wallace v. Jaffrec, $105 \mathrm{~S}$. Ct. 2479 (1985), which struck down an Alabama statute allowing a moment of "prayer or silence" in the public schools, neither the Court nor the party challenging the statute found any constitutional infirmity with the first of the three statutes at issue, AlA. CoDE (Supp. 1984) § 16-1-20, which allowed simple meditation, 105 S. Ct. at 2482. 


\section{Civil Religion}

the social and political contexts in which they arise. They could then evaluate them on that basis and, if they concluded that serious establishment clause concerns were implicated by any given practice, could offer creative suggestions that captured the social and political value of the rejected practice, thus taking the sting out of what are, understandably, very politically unpalatable decisions. ${ }^{89}$

\section{CONCLUSION}

The constitutional and political problem posed by the religious dimension of American public life that was identified at the ouset of this discussion, the problem of public religion, cannot be understood in isolation from the historical and social processes of which it is a part. In particular, public religion can be made comprehensible, both historically as well as constitutionally, only by recourse to the idea of civil religion as developed by the students of American religion. While recognizing the idea and reality of civil religion cannot make the ambiguities simply go away, it can help courts ground their decisions in a coherent understanding of the social and cultural realities before them. The idea of civil religion can serve as a supple tool with which courts can adequately comprehend the origins and function of public religion and do justice to enduring values while maintaining the integrity of the establishment clause.

89. For example, the school prayer cases generated an extraordinary backlash and uproar among the general public. See A. Stokes \& L. Pfeffer, supra note 11, at 378-82. 